Ivan Marković

Department of Croatian Language and Literature Faculty of Humanities and Social Sciences University of Zagreb ivan.markovic@yahoo.com

(iD https://orcid.org/0000-0003-0005-5768

\title{
Croatian Blends in the 1980s (Feral's First 10 Years)
}

Summary: The paper is a report on the yet unreaserched corpus of Croatian blends collected from the first ten yearly volumes of the satirical weekly Feral or Feral Tribune. Basic formal characteristics of the blends are further expounded. Three findings are brought forward. Firstly, blends were rare in Feral until 1989, when they became very frequent, and equal in form and content to blends in subsequent Feral Tribune. Secondly, in the 1980s there were more blends in the weekly Nedjeljna Dalmacija than in Feral, which was a supplement to Nedjeljna Dalmacija; this gives us a better idea of the general pulse of Croatian blending in the 1980s. Thirdly, comics author Ivica Bednjanec remains, as far as we know, the most prolific blend-maker of the decade.

The following was established regarding semantic and formal characteristics of the blends in Feral. First, $80 \%$ of a total of 210 blends are nouns. Second, $46 \%$ of blends consist of a name as one of their components. In $61 \%$ of cases, the name is the first blend component. Third, a relatively large number of blends have the acronym $(13 \%)$ as one of their components. In $69 \%$ of cases, the acronym is the first blend component. Fourth, the first blend component tends to be somewhat shorter in general. The ratio of the number of syllables in the analyzed corpus is $1.00: 1.18$. Fifth, there are extremely few blends with a simultaneous clipping of the ending of the first and the beginning of the second component. The blends of the analyzed corpus are based on the overlapping of the same phonetic material of the first and the second components.

Keywords: (lexical) blends, (lexical) blending, overlapping, Croatian, Ivica Bednjanec, Feral Tribune 
The title of this conference is the peripheral in Croatian language, literature and culture. Our linguistic subject will be triply peripheral - in terms of geography, frequency and register, i.e. of the language variety in which it occurs. We will present a report on yet unresearched blends in the Feral weekly in the first ten years of its publication (1983-1993). Let us start by explaining the peripheral character of the researched corpus. Firstly, in terms of geography, Feral was published at the time as part of the Nedjeljna Dalmacija weekly and the Slobodna Dalmacija daily, both regional papers in the sense that, outside of Dalmatia, they were mostly read by Dalmatians settled elsewhere. Feral Tribune (on the name and its changes, see below, § 3) gained recognition throughout Croatia only upon becoming an independent journal. One must keep in mind that the 1980s were the time of federative Yugoslavia and that the capital cities of the six constitutive republics all had their own daily papers. On the state level, the only dailies with somewhat wider-ranging influence and readership were the ones from Belgrade and Zagreb (e.g. Borba, Politika, Vjesnik; none but Borba had editorial offices and special editions in all six capital cities). Secondly, in terms of frequency, in the 1980s blends in the Croatian language were rare, and the word formation process of blending was not nearly as prolific as it is today. Incidentally, this has nothing to do with blends being, back then as well as today, mostly nonce words. Thirdly, in terms of register, Feral was a satirical newspaper supplement, and blending in Croatian is to this day most frequent precisely in the language of newspapers and advertising, in slang, to some extent in terminology, but it hardly occurs in general language. In Croatian, blending is not a neutral linguistic process (for that matter, this probably applies to every language).

The collected material will show that prolific blending - a distinctive feature of Feral Tribune in the 1990s and 2000s - cannot be found until 1989, when it almost abruptly flared up. We may therefore put forward right away the conclusion of this paper: at this level of research into Croatian blends, we can say that, in the 1980s, the most prolific blend-maker was comics author Ivica Bednjanec, comics being another phenomenon that was neglected and peripheral in the linguistic sense. Feral would take over the pole position in blending only at the very end of the 1980s and in the 1990s.

The paper is structured as follows: first we provide basic information on blends and blending in Croatian, particularly on blending in the 
1980 s, as much as is known about it so far (see $\S 2$ ), then we present the necessary data on Feral (see $\S 3$ ), and finally we report on the findings of our research (see $\S \S 4.1-3$ ). In the appendix to the paper we provide a list of the blends we have found as a possible addition to the existing Croatian Dictionary of Blends ${ }^{1}$.

\section{2.}

Blends are words created by deliberate concatenation of non-meaningful parts of two existing words, specifically the beginning of one and the ending of the other, generally with loss of phonetic material of both source words. This is the prototypical, the canonical case ${ }^{2}$. If we elaborate on such a definition for our purposes, we obtain the following. Firstly, in our view, it is key for blends that their constitutive elements are non-meaningful, i.e. that they are not morphs. This does not mean that they may not or cannot be morphs, but that generally they are not. In this respect blending differs essentially from other processes of word-composition, including composition with affixoids (this is why, for instance, we do not take into consideration here any words with the prefixoid dem- 'democratic', which occur frequently in Feral, e.g. dembudizam, demkroatizam, demrealizam) ${ }^{3}$. Secondly, blends are created deliberately, intentionally. This excludes from (this) discussion the ones created either by a lapse in speech or through crossing of cognate words in the distant past or through simple contraction of phonetic material (cf., e.g., Isus Krist 'Jesus Christ' $\rightarrow$ Isukrst). Thirdly, there can be more source words, for instance three, very rarely four ${ }^{4}$, but prototypically there are two ${ }^{5}$.

\footnotetext{
${ }^{1}$ Ivan Marković, Ivana Klindić, and Iva Borković, Hrvatski rječnik stopljenica (Zagreb: Filozofski fakultet Sveučilišta u Zagrebu, Odsjek za kroatistiku, Katedra za stilistiku, 2016).

${ }^{2}$ For various definitions as well as core and marginal realizations of blends, see, e.g., Michael H. Kelly, "To »brunch« or to »brench«. Aspects of Blend Structure," Linguistics, vol. 36, no. 3 (1998): 579-590, Laurie Bauer, "Blends. Core and Periphery," in Cross-disciplinary Perspectives on Lexical Blending, eds. Vincent Renner, François Maniez, and Pierre J. L. Arnaud (Berlin: De Gruyter Mouton, 2012), 11-22, Vincent Renner, François Maniez, and Pierre J. L. Arnaud, "Introduction. A Bird's-eye View of Lexical Blending," in Cross -disciplinary Perspectives, eds. Renner, Maniez, and Arnaud, 1-9, and the bibliography provided therein.

${ }^{3}$ In socialist times, a similar prefixoid in Croatian was soc- 'socialist'.

${ }^{4}$ Cf. Ivan Marković, "Od Oca do Ćaće. 150 godina hrvatskih stopljenica," in Marković, Klindić, and Borković. Hrvatski rječnik stopljenica.

${ }^{5}$ For reasons not quite clear, Kelly excludes from his analysis of English blends the ones with more than two source words, such as compushity (compulsion $\times$ push $\times$ necessity) (see
} 
Fourthly, blending generally involves clipping or removal of the ending part of the first source word (apocope of the left source word) and of the beginning part of the second source word (aphaeresis of the right source word). But, again, not necessarily, since words with only one clipped component, as well as words with overlapping of phonetic material of the ending of the first source word and of the beginning of the second, are also considered blends. This fact makes it more difficult to perform a precise linguistic analysis of blends, for in overlapping it is not easy to speak of a morphic juncture or a syllabic boundary (cf. below $\S 4.3$ ). Fifthly, marginal blends also include the ones where one source word completely overlaps with the other, which is then in writing often stressed graphically (cf., e.g., SFR $a J \leftarrow$ SFRJ 'Socialist Federative Republic of Yugoslavia' $\times$ Ger. IZimmer/ frei, Cr. [fraj]). Sixthly, the semantic interrelations of source words can be coordinative and subordinative; more precisely, they can be hybrid, additive, polyvalent, tautologous and determinative $^{6}$, but we consider this to be explanatory, not defining ${ }^{7}$. And finally, seventhly, words made up only of beginnings of source words (e.g. Maspok $\leftarrow$ masovni 'mass' + pokret 'movement', agitprop $\leftarrow$ agitacija 'agitation' + propaganda, Benelux $\leftarrow$ Belgium + The Netherlands + Luxemburg) are not considered blends, but rather acronyms of some kind.

A word or two on blending in the Croatian language. As far as we $\mathrm{know}^{8}$, in the second half of the 19th century politician and writer Ante Starčević first used deliberate blends in Croatian in his satirical articles. We cannot be sure regarding the word novinkar, but regarding the other four examples that follow, it is safe to say they are very probably deliberate blends:

kloakofonia (kloaka 'cesspool' $\times$ kakofonija 'cacophony') (1879)
Magjarolac (Magjar 'Hungarian' $\times$ Tirolac 'Tyrolin') $(1867)$
monantonia (monotonija 'monotony' $\times$ onanija 'onanism') (1879)

Kelly, "To »brunch« or to »brench«", 582). We mention this merely as an addition to all problems which can possibly occur in the approach to blends.

${ }^{6}$ Cf. Bauer, "Blends". Bauer takes over the classification from V. Renner's 2006 doctorate.

${ }^{7} \mathrm{Cf}$. the state of affairs with compound words. They can also be subordinative and coordinative, but as interesting as it may be, and as greater in number as the subordinative ones are, this does not define them as compound words. Likewise, it may be interesting that the vast majority of blends are coordinative, but this does not define them as blends.

${ }^{8}$ See Marković, "Od Oca do Ćaće", and Ivan Marković, "Bilješke o jeziku Ante Starčevića," Filologija 71 (2018): 75-114. 
novinkar (novinar 'journalist'× ?hodkar 'informant, snitch') $(1850 / 1851)$

samosralac (samostalac 'autonomist' $\times$ liberalac 'liberalist' $\times$ srati 'to crap') (1879)

We then keep track of blending through writers Ante Kovačić and Antun Gustav Matoš at the turn of the 19/20th centuries and throughout the 20th century as a marginal word formation process, which no writer developed to a significant extent. So it remained until the 1970s and 1980 s, when blending started to occur more frequently in slang (we can attest to this for the Zagreb slang from our own linguistic experience) and in comics by Ivica Bednjanec. The latter wrote his satirical comics in colloquial language, often making fun of the sterile language of politics and bureaucracy. Bednjanec first published the series Nježni robijaš (Gentle Convict) ${ }^{9}$, then, from mid-1970s to mid-1980s, the series Nježni sport (Gentle Sport), featuring in the popular Zagreb sport weekly SN revija ${ }^{10}$. The Croatian Dictionary of Blends comprises almost 300 blends by Bednjanec ${ }^{11}$, which makes his comics by far the most abundant source of blends in the period discussed here. Here is a dozen, just as an illustration:

dolijun (dolar 'dollar' $\times$ milijun 'million') (1982)

đimpanza (đipati 'to bounce around' $\times$ ćimpanza 'chimpanzee') (1984)

folonter ( fol 'lie, deception' $\times$ volonter 'volunteer') (1982)

humoroid (humor 'humour' $\times$ hemoroid 'hemorrhoid') (1981)

intervjunferirati (intervjuirati 'to interview' $\times$ junfer 'male virgin') (1981)

košargaćica (košarkašica 'female basketball player' $\times$ gaćice 'panties') (1983)

lošinjariti (Lošinj × lešinariti 'scavenge') (1982)

Maznigan (maznuti 'to hit' $\times$ Marijan /Beneš/) (1983)

nogolomet (nogomet 'football' $\times$ lom 'rupture') (1981)

\footnotetext{
9 See Ivica Bednjanec, "Nježna magija," Super strip BIS, Zagreb, no. 18 (1975): 37-44, and Ivica Bednjanec "Nježni robijaš," Kerempuh. Humoristički list, Zagreb, vol. II-III, no. 11-25, Mar 1975-May 1976.

${ }^{10}$ See Ivica Bednjanec, Nježni sport. Satirička enciklopedija sporta u stripu (Zagreb: Mladost, 1980), and Ivica Bednjanec, "Nježni sport," SN revija, Zagreb, vol. VI-IX, no. 222429, 7 Jan 1981-26 Dec 1984.

${ }^{11}$ See Marković, Klindić, and Borković, Hrvatski rječnik stopljenica.
} 
pečalbasketar (pečalba 'working abroad' $\times$ basketar 'male basketball player') (1983)

slabilizacija (slab 'weak' $\times$ stabilizacija 'stabilisation') (1981)

veseličanstven (veseo 'merry' $\times$ veličanstven 'magnificent') (1981)

In Croatia, comics is not, and never has been, a mainstream medium, it has always been and remains merely a part of popular culture (we must keep in mind that in this paper we speak of a time when popular culture was not mainstream). But in the 1980s, with the group Novi kvadrat, comics attained the status of (high) art. Linguists never paid any attention to comics, which is why the language of comics was left outside of their range and was never given a fitting linguistic description. Consequently, wordplays by Bednjanec remained unknown as well, and there is also no description of the playful language of comics author Dubravko Mataković, who has been publishing from mid-1980s to the present day. To put it simply, comics language is a language of the margin, of periphery, unknown and undescribed. Comics readers have never been sufficiently numerous or socially influential for comics language to have greater impact on general language. Comics language influenced only slang, which took over some witty phrases from comics such as Alan Ford or comics available in Croatia in the Serbian translation, which was perceived by Croatian-speaking readers as surprising and somewhat funny. ${ }^{12}$

Interim conclusion: as far as we know, in the 1980s blending was still a rare and marginal phenomenon in the Croatian language. Thereafter, from the 1990s to the present day, blending, as a process of forming occasionalisms in Croatian, has been greatly developed in slang and in comments at internet forums, in newspaper and commercials language, in translations of movies, TV-shows and fictional literature. Moreover, blends have been described linguistically, we have learned a lot about the development of blending in Croatian (of which until recently we knew nothing), a dictionary of blends has been compiled ${ }^{13}$ and research papers on blends are produced ${ }^{14}$.

${ }^{12}$ Cf., for instance, the phrase from the comic book series Talični Tom (i.e. Lucky Luke) Serb. brži od sopstvene senke 'faster than his own shadow'.

${ }_{13}$ Marković, Klindić, and Borković, Hrvatski rječnik stopljenica.

${ }^{14}$ Of which we may mention Krešimir Bagić, “Stopljenica. Riječ, figura, kultura.” In Svijet stila, stanja stilistike. Proceedings from the colloquium, 13 Feb 2015 (Zagreb: Filozofski fakultet, Stilistika, 2015), Ivan Marković, "Od Oca do Ćaće," Barbara Štebih Golub, "Stopljenice u medijskome i reklamnome diskursu suvremenoga hrvatskog jezika," Poznańskie Studia Slawistyczne 13 (2017): 195-208, and the bibliography provided therein. For compa- 
The regime-opposing weekly Feral Tribune certainly contributed to this development. It was published independently from 1993 to 2008, and blending was one of its main stylistic and attractive procedures. Blends collected from the 15 years of Feral Tribune take up approximately $30 \%$ of the Croatian Dictionary of Blends ${ }^{15}$, some 1500 out of a total of more than 5000 words. After Feral Tribune was discontinued, its editors and principal authors scattered through other media and still rank among the most prolific blend-creators. Here is but a handful of recent examples found in speech and writings of Viktor Ivančić, Predrag Lucić and Boris Dežulović:

infarmacija (informacija 'information' $\times$ farmacija 'pharmacy') (V. Ivančić, lecture at Faculty of Humanities and Social Sciences Zagreb, 4 May 2009)

mosteoartroza (Most 'Bridge', political party of the opposition $\times$ osteoartroza 'osteoarthrosis') (P. Lucić, Novi list, 17 Aug 2016) knjigorporativan (knjiga 'book' $\times$ korporativan 'corporative') (B. Dežulović, N1, 6 Jun 2017)

šljaman (šljam 'scum' × šaman 'shaman') (V. Ivančić, Novosti, 23 Jun 2017)

Kičmanbegović (/Ivica/ Kičmanović × /Zlatko/ Hasanbegović) (B. Dežulović, N1, 19 Dec 2018)

All issues of independently published Feral Tribune were made available in the digital format ${ }^{16}$, which enabled the authors of the Croatian Dictionary of Blends to research the material. But there was no access to the first ten yearly volumes, when Feral was a supplement to the Nedjeljna Dalmacija weekly and later to the Slobodna Dalmacija daily. The aim of this paper is to rectify this lack, to peruse the first ten yearly volumes, and to reach three objectives. Firstly, to examine whether there were any blends in Feral in the 1980s, when they occurred and what they were like. Secondly, by so doing, to gain better insight into blending as a word formation process in the Croatian language in the 1980s. Thirdly, to present material to authors of the Croatian Dictionary of Blend $s^{17}$ which may be added to possible subsequent editions.

\footnotetext{
rison with other Slavic languages and linguistic comparison in general, see, e.g., Renner, Vincent, François Maniez, and Pierre J. L. Arnaud, eds., Cross-disciplinary Perspectives on Lexical Blending (Berlin: De Gruyter Mouton, 2012).

${ }^{15}$ Marković, Klindić, and Borković, Hrvatski rječnik stopljenica.

${ }^{16}$ Cf. Feral Tribune (Sarajevo: Mediacentar, 2010), 4 DVD.

${ }^{17}$ Marković, Klindić, and Borković, Hrvatski rječnik stopljenica.
} 
Let us provide some necessary data on the beginnings and development of Feral ${ }^{18}$. The first issue of humour supplement Feral was published in the Split weekly Nedjeljna Dalmacija on 16 October 1983. Its initiator and first editor was Đermano Senjanović, who came up with its name ${ }^{19}$. From the second, non-numerated issue of 23 October 1983 - for more on numeration, see below - until 12 August 1984, it was published under the heading Nedjeljni politički zabavnik. Senjanović left Feral on 5 February $1984^{20}$. At first the supplement usually took up one newspaper page, with rare exceptions such as new-year issues of 1 January 1984 or 5 January 1986, when it took up two, while from 9 February 1986 it often took up even less than an entire page, i.e. about three quarters thereof. As of 10 September 1989, it began to extend beyond one page, at times to two entire pages, and as of 19 November 1989, the latter became a rule rather than an exception.

Since 28 October 1984, the editors of the Feral supplement were Viktor Ivančić and Velimir Marinković, award-winning editors of the student gazette of the Faculty of Electrical Engineering, Mechanical Engineering and Naval Architecture (FESB) in Split ${ }^{21}$. The editorial board of Feral would subsequently consider this to be the first issue, although by then some 53 issues had been published ${ }^{22}$. Predrag Lucić, signed by his full name, first published a contribution on 17 February 1985; until then he had several contributions under the pseudonym Captain A. In the issue of 12 January 1986 the editors announced a discontinuation, but on 19 January 1986 the next issue of Feral was published, though

\footnotetext{
${ }^{18}$ The data is based on our own knowledge of the material. All additions based on the chronology provided in Pavelić's monograph on Feral Tribune are clearly marked, cf. Boris Pavelić, Smijeh slobode. Uvod u Feral Tribune, second edition (Rijeka: Adamić, 2015).

${ }^{19}$ See Pavelić, Smijeh slobode.

${ }^{20}$ Pavelić, Smijeh slobode.

${ }^{21}$ In 1984, the FESB gazette won the important and highly regarded national award "Sedam sekretara SKOJ-a" (see Pavelić, Smijeh slobode).

${ }^{22}$ Many signals make it quite clear that later editors of Feral Tribune did not perceive Feral before the arrival of V. Ivančić as "their own". Primarily the numeration, starting from issue no. 256 (12 Nov 1989), although by then, realistically, more than 300 issues had already been published. Secondly, the anniversaries, which were marked on the pages of Feral in October 1988 (fourth), October 1989 (fifth), and October 1992 (eighth). Thirdly, statements by editors V. Ivančić, P. Lucić and B. Dežulović, e.g. V. Ivančić's statement in his text in Slobodna Dalmacija on 5 and 6 January 1993, to the effect that "the first issue of the satirical supplement "Feral" was published on 28 October 1984". On the dating of Feral, see also Pavelić, Smijeh slobode.
} 
with only Ivančić as editor. Already in 1986 and 1987 charges were pressed against Ivančić and Marinković for provocative texts and illustrations $^{23}$. In December 1986 Feral was not published, and no issue appeared between 22 February 1987 and 8 March 1987 as well as on 12 April 1987.

From time to time the editors would play around with the name: thus the issue of 24 March 1985 was entitled Listak za ukrase prirode, the issue of 26 May 1985 - Feralturist, and the issue of 8 September 1985 - Feralić. Occasionally there was no title, for instance when the entire issue consisted of pastiche comics, such as on 24 February 1985, 28 July 1985 or 29 November 1987. From 19 July 1987 to 3 July 1988 for almost a year - the supplement was called Feral turbo, from 10 July 1988 to 21 August 1988 and from 18 September 1988 to 3 September 1989 - again for an entire year - the title was Feral alko, on 28 August 1988 it was Feral eкcnpec (after the Belgrade daily Politika ekspres) ${ }^{24}$, on 4 September 1988 the title was Feral sedativ, and on 30 October 1988, again, Feral turbo. As of 12 November 1989, i.e. since the first numerated issue (256), it bore the title Feral Tribune and acquired the graphic layout it is remembered for. This would remain so until the discontinuation in 2008. The name and logo were conceived by Boris Dežulović, who combined Feral with the name of the New York newspaper Herald Tribune. ${ }^{25}$

Ivančić was editor until the start of his mandatory military service in July $1988^{26}$. In many issues V. Marinković, A. Anković or A. Šuljak were signed as co-editors. In the issue of 30 November 1986 the editor was M. Vuković, and in the issues of 14 February 1988 and 21 February 1988 the editors were M. Šarenac and R. Rodić. The issue of 14 June 1987 was co-edited by Ivančić, Marinković and Lucić; this was the first time Lucić was signed as member of the editorial board. Late in August 1988 Feral caused the first ban of an issue of Nedjeljna Dalmacija in 45 years of publication; the ban was annulled by judge Branko Šerić ${ }^{27}$, presently a well-known attorney. One of the reasons for the ban was the song Mlada Partizanka bužu imala (Young Partisan Girl Had a Hole),

\footnotetext{
${ }^{23}$ They were not sentenced - either the court of first instance acquitted them or the process was never completed due to the disintegration of SFRJ.

${ }^{24}$ It was the time of gatherings in support of S. Milošević, reported by the Belgrade press in a propagandist tone.

${ }^{25}$ Pavelić, Smijeh slobode.

${ }^{26}$ Pavelić, Smijeh slobode.

${ }^{27}$ Pavelić, Smijeh slobode.
} 
a parody of the Yugoslav Partisan song Mlada partizanka pušku nosila (Young Partisan Girl Carried a Rifle), which was published in Feral on 28 August 1988 next to a picture of the Partizanka (Young Partisan Girl) ferry, which was actually damaged by colliding with a pier in the Split harbour. B. Dežulović was co-editor with Lucić from 10 July 1988, with the editorial slogan "Fuel added to the flames by: Studio »Ludež«" (= P. Lucić and B. Dežulović), ludež possibly meaning 'craziness' in Croatian ${ }^{28}$. Upon Ivančić's return from military service on 16 July 1989, the editorial slogan was changed to "Backfiring on us: Studio »Viva Ludež«" (= V. Ivančić, P. Lucić and B. Dežulović). This was Feral's most renowned editorial trio, a sort of metaphor of Feral.

The last issue of Feral Tribune in Nedjeljna Dalmacija, no. 301, was published on 30 September 1990. In the next issue of 7 October 1990 Nedjeljna featured the supplement Feralburger and invited applications for the position of editor, but in the end it came to nothing. As of 30 December 1990, Dubravko Mataković published his comic Prot Pictures in the section of Nedjeljna Dalmacija hitherto taken up by Feral. ${ }^{29}$

From 23 November 1990 until 3 March 1993, i.e. from issue no. 302 until issue no. 414, Feral Tribune was published once a week in the Split daily Slobodna Dalmacija. Throughout the run it consisted of four pages. Forceful privatisation of Slobodna Dalmacija made the editorial board of Feral Tribune leave the newspaper in March 1993 and launch the independent Feral Tribune, the first issue of which (416) was published on 1 June 1993. Prior to this, issue no. 415 of Feral Tribune was a guest in the first, April issue of the newly-launched Zagreb journal Erasmus. The independent Feral Tribune soon became a serious, respectable and influential weekly, to which the satirical part became a supplement.

Finally, let us add that 18 October 1999 saw the publication of the last issue with B. Dežulović, who then left Feral Tribune. The very last issue of Feral Tribune was published on 20 June 2008. Đ. Senjanović Ćićo passed away on 18 March 2013. P. Lucić, who wrote a daily column in the Rijeka daily Novi list, passed away on 10 January 2018.

\footnotetext{
${ }^{28}$ From 1988 to 1990 B. Dežulović was also co-editing "Le Spizd" supplement to the Omladinska iskra fortnightly (Youth sparkle), at first with R. Stefanović, then in 1989 and 1990 with s P. Lucić; the editorial slogan was "Studio Prdež" (= Predrag Lucić i Boris Dežulović), prdež meaning 'fart' in Croatian.

${ }^{29}$ Published soon thereafter in comic books: Dubravko Mataković, Prot. Ratno izdanje (Zagreb: s. n., 1991), Dubravko Mataković, I jope Prot pictures. Pterodaktiličarstvo za početnike (Sisak: Centar za kulturu Vladimir Nazor et al., 1992).
} 
V. Ivančić is presently writing for the weekly Novosti and the internet portal Peščanik (Serbia), while B. Dežulović is writing for Novosti and the internet portal N1.

4.1.

With the increasing size of Feral (as we said, at first in 1983 one page, from the end of 1989 two pages, from the end of 1990 four pages), and with the arrival of new associates and editors (V. Ivančić in 1984, P. Lucić in 1985, B. Dežulović in 1988), the contents of Feral changed and expanded, and new textual forms appeared in it. Initially Feral conveyed brief ambiguous news, often with a witty comment, original aphorisms, original humoristic sketches, occasionally caricatures. The arrival of V. Ivančić and soon thereafter P. Lucić brought new genres. For instance, already in his first issue of 28 October 1984 Ivančić wrote Militaristička brojalica (Military Rhyme), a parody of the nursery rhyme Eci peci pec, which might as well have been taken from a poem by Robi K. from class II ${ }^{30}$. As Pavelić wrote, "Week after week, Feral would increasingly cease to be a weekly portion of urban entertainment, [...] and become a self-assured challenger to politics and society which had lost all sense of direction and purpose" ${ }^{\prime 31}$. Yugoslavia, which was falling apart due to an economy in tatters and to nationalism, senseless ideology and bureaucracy, a sterile state apparatus and universal stupidity oozing day after day from the media, all became targets of Feral's sharp and lightning-quick satire. For instance, on 20 January 1985 A. Kuštre wrote in Nedjeljna Dalmacija the article "Sasušeni jezik" ("Dried-up Language"), in which he denounced the poverty of the language of Split's youth, asserting that its speech was reduced to three adverbs - skroz 'totally', $k a$ 'like' and masu 'bunch'. The following week (27 Jan 1985), almost out of spite, the entire Feral was composed of texts teeming precisely with the three words, i.e. of texts with titles such as this (highlight added):

Ovo je ka molba! 'This is, like, a request!'

Ovo je masu ogavno! 'This is a bunch of garbage!'

Ovo Robi K. ka čita novine 'This is Robi K., like, reading the paper'

\footnotetext{
${ }^{30}$ Ivančić is still writing the long-running and popular column From Robi K.'s Notebook or Robi K.'s Notebook.

${ }^{31}$ Pavelić, Smijeh slobode, 49-50.
} 
Ovo je skroz dobra baza! 'This is a totally good joke!'

Ovo je skroz dobro - masu filmova! 'This is totally good a bunch of movies!'

Feral would come to boast the following trademarks: playing with language ${ }^{32}$, satyrical pastiche, parody, travesty, i.e. imitations of traditional newspaper genres and sections such as news, ads, obituaries (e.g. an obituary for a character from the soap-opera Dynasty, which was very popular at the time, signed by the "Working Class of Yugoslavia"), then photo-montage and collage, news from the future (e.g. 1980s news from 2005 or 2008), self-help advice, made-up transcripts of conversations allegedly recorded in secret (e.g. between tennis player Jimmy Connors and singer Dolly Parton), made-up tests such as can be found in young girls' magazines, images from comics with new text (e.g. Lucky Luke, Alan Ford, Smurfs, Flash Gordon), making fun of real news through recontextualisation with a comment, or putting together of unrelated titles and headings in new combinations, and finally, the increasingly frequent wordplay. All of it can actually be considered as types of notional blending ${ }^{33}$. It was only a matter of time before blending descended from higher levels, e.g. from the syntagm level (cf. Antun Mihanović $\times$ Draža Mihajlović $\rightarrow$ Antun Mihajlović, FT, 23 Nov 1990; first name and family name of author of Croatian national anthem and of Serbian Chetnik leader from World War Two, respectively) to the word level, i.e. before lexical blends appeared.

Blends began to occur in greater numbers when Feral started publishing longer texts, when late in 1989 the trio of editors Viva Ludež became permanent, when Feral was renamed to Feral Tribune and, lastly, when late in 1990, in Slobodna Dalmacija, it expanded to four

\footnotetext{
${ }^{32}$ Indeed, as part of deliberate poetics; cf. Pavelić, Smijeh slobode, 112-113 for V. Ivančić's words on the subject: "If any of it retains value, it is in fact only the handling of language, into a number of variations, from jokes, alteration of words or letters, to interest in the lexicon itself. I started writing Robi K., for instance, exclusively out of interest in the city's slang. In the eighties Robi was not created due to political activism, but to my fervent interest in the city's slang [...]".

${ }^{33}$ In the sense analysed, e.g., by Sigmund Freud, Die Traumdeutung. Gesammelte Werke, Bd. II-III (London: Imago Publishing Co., 1900), Sigmund Freud, Der Witz und seine Beziehung zum Unbewußten. Gesammelte Werke, Bd. VI (London: Imago Publishing Co., 1905). Here notional blending is neither used terminologically nor is it identified with more elaborate conceptual blending from Gilles Fauconnier and Mark Turner, The Way We Think. Conceptual Blending and the Mind's Hidden Complexities (New York: Basic Books, 2002), where lexical blends are discussed in the relatively brief section "Formal blending", pp. 365-369.
} 
pages. We cannot say for certain how the boom of blends is connected to all that has been said above or what exactly caused it. We simply take note of the fact. Namely, back in 1988 the largest text in Feral was the column From Robi K.'s Notebook, which was for a time moved to the forefront second page of Nedjeljna Dalmacija, then it was returned to Feral, and in July 1988 it was interrupted due to Ivančić starting his military service. Only in 1989 did Feral begin to feature longer texts, and there were less caricatures and images. Since then we observe a rapid increase in the number of blends.

Like all other means of expression, Feral would use blends to comment on current events and expose them to ridicule. For instance, when in 1990, instead of Dalmatia, the regime's media started using the term South Croatia, which naturally irritated Dalmatians, Feral immediately came up with the blend Hrvatinac:

Hrvatinac (Hrvat 'Croat' $\times$ Dalmatinac 'Dalmatian') (FT, 29 Jul 1990)

Parliament member I. Bobetko throwing his briefcase at Parliament member R. Tanjga (a Serb who spoke about the new "Ustashoid" Croatian government) led to the publication of a text with the following blends:

Bombetko (bomba 'bomb' × /Ivan/ Bobetko) (FT, 7 Aug 1991)

torblon (torba 'bag' $\times$ tromblon 'rifle grenade') (FT, 7 Aug 1991)

Incidentally, in connection with the event, Bugarski mentions the blend aktentat (aktovka 'briefcase' $\times$ atentat 'assassination') ${ }^{34}$; we find no token thereof in Feral, and there is none in the Croatian Dictionary of Blends. ${ }^{35}$

\section{2 .}

Quite simply, numerically speaking, in the first 10 years of Feral (1983-1993) we found cca 205 blends, the shortcoming of the human eye and the peruser's focus notwithstanding. The frequency

\footnotetext{
${ }^{34}$ See Ranko Bugarski, Žargon. Lingvistička studija, Second edition (Beograd: XX vek, Knjižara Krug, 2006), 196, and Ranko Bugarski, Sarmagedon u Mezopotamaniji. Leksičke skrivalice (Beograd: XX vek, Knjižara Krug, 2013), 33, 99.

${ }^{35}$ Marković, Klindić, and Borković, Hrvatski rječnik stopljenica.
} 
varied drastically between the first and second five-year period. In 1983 there were no blends, from 1984 to 1988 we found about 5-6 blends, while from 1989 to 1993 we found the remaining 200, almost 20 of which right away in 1989, four times more than in the first five years.

We made a somewhat surprising discovery: leafing through $\mathrm{Ne}$ djeljna Dalmacija in order to get to the Feral supplement, naturally, without reading everything, only with cursory perusal of the titles, we found about ten blends from 1984 to 1986, and five more in 1989 (in other annual files we found none), which is actually more than we found in Feral in those years. Columnist Grintalo (Whiner) stood out in terms of blending; in 1986, he put blends in the titles of his column ${ }^{36}$. Here are the blends:

kapijalizam (kapitalizam 'capitalism' $\times$ socijalizam 'socialism') (H. Biščević, ND, 1 Oct 1989)

kradlj (krasti 'to steal' ps. 3. sg. krade 'he steals' $\times$ kralj 'king') (Grintalo, ND, 21 Nov 1986)

kradljica (krasti 'to steal' ps. 3. sg. krade 'she steals' $\times$ kraljica 'queen') (Grintalo, ND, 21 Nov 1986)

krebil (kreten 'cretin' $\times$ debil 'moron') (T. Bebić, ND, 1 Apr 1984) majilili (maj 'May' $\times$ aprilili 'April fool') (Grintalo, ND, 4 May 1986)

manufraktura (manufaktura 'manufacture' $\times$ fraktura 'fracture') (Grintalo, ND, 30 Mar 1986)

nogbi (noga 'foot' $\times$ ragbi 'rugby') play with a ball in the shallows played since the 1950s on the Bačvice beach in Split (T. Bebić, ND, 6 Jan 1985)

porock (porok 'vice' $\times$ rock) $(Z$. Gall, ND, 29 Jan 1984) refolucija (refolution $\leftarrow$ reforma 'reform' $\times$ revolucija 'revolution') (H. Biščević, ND, 1 Oct 1989)

REMek-djelo (R.E.M. × remek-djelo 'masterpiece') (Z. Gall, ND, 4 May 1989)

sfraj (SFRJ 'Socialist Federative Republic of Yugoslavia' $\times$ Ger. / Zimmer/ frei, Cr. [fraj]) (Grintalo, ND, 29 Jun 1986)

\footnotetext{
${ }^{36}$ We have not been able to find out who Grintalo was. Nonetheless, we thank Ivo Žanić and his acquaintances - all of them wrote in Nedjeljna Dalmacija and Slobodna Dalmacija in the 1980s, some were even editors of Feral - for the effort they put into it. We can say with certainty, though, that the column Čitajte grintajući (Read Whiningly) was not part of Feral, although it was published on the same page.
} 
socitalizam (socijalizam 'socialism' $\times$ kapitalizam 'capitalism') (H. Biščević, ND, 1 Oct 1989)

tenkovina (tenk 'tank, armoured military vehicle' $\times$ tekovina 'attainment') (ND, 18 Jun 1989)

Some are terms taken over from the English language (cf. examples by H. Biščević) ) $^{37}$, some are jokes in titles (cf. Grintalo's and the examples by Z. Gall), some would also be used later in Feral Tribune (e.g. tenkovina $^{38}$, while nogbi proves the findings of our research - that occasional blending in Croatian slang far preceded any linguistic knowledge about blending and blends in the Croatian language. Let us repeat what is key: up to 1989, blending in Feral was less prolific than blending found in Nedjeljna Dalmacija as a whole ${ }^{39}$. Up to 1989, in Feral we came across only the following handful of blends:

deflormaster (deflorirati 'to deflower' $\times$ flomaster 'felt-tip pen') (FT, 8 Sep 1985)

stolicizam (stolica 'chair' $\times$ stoicizam 'stoicism') $(\mathrm{FT}, 8$ Jan 1984) satirikonj (satirikon 'satyricon' $\times$ konj 'horse') (FT, 4 Mar 1984) sivotinjski (SIV 'Federal Executive Council' $\times$ životinjski adj. 'animal') (FT, 3 Jul 1988)

Štrumpferal (štrumpf ‘Smurf’ $\times$ Feral) $(\mathrm{FT}, 24$ Feb 1985)

Štrumpfsar (štrumpf 'Smurf' $\times$ Gusar 'Pirate') (FT, 24 Feb 1985)

And then, in 1989, a veritable explosion of blends. Of course, we will not list them all (they are provided in the Appendix to the paper). Instead, in the next section we will merely outline the basic characteristics of their content and form.

\section{3.}

Since Croatian blends - including the ones in Feral - are mostly nonce words, it is not easy to speak of their structure, for there are simply none which have been incorporated in the general lexicon and

\footnotetext{
${ }^{37}$ Direct takeover from foreign languages and literal translation, particularly from English, are very frequent ways in which blends have always been introduced into the Croatian language (see Marković 2016).

${ }_{38}$ Cf. Marković, Klindić, and Borković, Hrvatski rječnik stopljenica, s. v.

39 Thence the presupposition and guideline for further research: an overview of other Croatian newspapers from the 1980s would probably yield the equal quantity of blends as Nedjeljna Dalmacija.
} 
could thus set the standard (assuming the ones more acceptable to native speakers are easier to incorporate). Be that as it may, certain characteristics may be singled out. Everything we expound here regards the 210 blends included in the alphabetical list in the Appendix. ${ }^{40}$

As for the four most numerous word classes, nouns are by far the most represented. The list includes 169 nouns $(\approx 80 \%), 33$ adjectives $(\approx 16 \%), 4$ verbs $(\approx 2 \%)$, and 5 adverbs $(\approx 2 \%)$. The data for nouns and adverbs match the data obtained by analysis of the Croatian Dictionary of Blends $s^{41}$, for which we will take an approximate number of 5250 entries. The entries comprise cca 4230 nouns $(\approx 81 \%)$, cca 580 adjectives $(\approx 11 \%)$, cca 290 verbs $(\approx 5 \%)$, and cca 135 adverbs $(\approx 2,5 \%)$. We see that a larger and more varied corpus yields an increased percentage of verbs and a decreased percentage of adjectives.

Most conspicuous in the corpus is the frequency of two types of source words: names and acronyms (incidentally, acronyms themselves are quite often names) ${ }^{42}$. At least one of the blend's components is a name in 96 words of our corpus $\approx 46 \%$ ), 37 of which contain two names, while 59 contain one. This fact is not conducive to incorporation of a blend into the general lexicon - all blends containing names are in fact highly dependent on the current extralinguistic context, they soon become outdated and lose all possibility to acquire any long-lasting meaning. Since it is assumed that, in the order of source components, the first will be more prototypical ${ }^{43}$, we must take a look at the order of names in the 59 words (out of 210) which contain one name ${ }^{44}$. In 36 of them the name is the first component, and in 23 words the name is the second $(61 \%$ : $39 \%$ ). This finding corresponds to some extent to Kelly's finding for the English language -26 out of 37 blends have the prototypical component in the initial position ${ }^{45}$. This is not to say that names are prototypical nouns, merely that they are informationally more prominent. Names are

\footnotetext{
40 The Seral Orjun syntagm will be counted as two blends.

${ }^{41}$ Marković, Klindić, and Borković, Hrvatski rječnik stopljenica.

${ }^{42}$ Everything that has an individual referent is here considered a name. Consequently, e.g., Cr. nouns such as Hrvat (Croat), Srbin (Serb), Dalmatinac (Dalmatian), Vlaj (man from hinterland of Split), Indijanac (Native American) or Srpska autonomna oblast (SAO, Serbian Autonomous District) are not included in that category, while, e.g., toponyms, book titles or company names are here considered names.

${ }^{43}$ Cf. Kelly, "To »brunch« or to »brench«," and Bauer, "Blends".

${ }^{44}$ Let it be noted that Bauer, "Blends", 13, drew upon the 2010 work by G. Lalić-Krstin and S. Halupka-Rešetar for the fact that in Serbian prototypicality is not an important factor of the order of components in blends.

${ }^{45}$ Kelly, "To »brunch« or to »brench«," 583.
} 
extremely frequent components of Croatian blends ${ }^{46}$, and we assume that research of a more extensive corpus would confirm that in $3 / 5$ cases the name would be the first component. Consequently, it is interesting that among the 15 blends from Nedjeljna Dalmacija (see § 4.2) only two have a component that is a name, actually an acronym (rock-group R.E.M. and SFRJ).

We find an acronym in 28 words $(\approx 13 \%$ of 210$)$. This includes Hadezejot and $u l j u d b a$, which we consider composed of two acronyms, which means that there are 26 words with one initial acronym. In 18 of them the acronym is the first component, and in 8 words the acronym is the second $(\approx 69 \%: 31 \%)$. Thus, just like names, acronyms have the initial position in most cases, more than could be deemed accidental.

Furthermore, it is found in English that the order of components in a blend is influenced by their length. To put it simply, shorter words, the ones with less syllables, are more likely to have the initial position ${ }^{47}$. In order to check the state of affairs in Croatian, we have simply calculated the average number of syllables of first and second components of twocomponent blends. In this regard, we must keep in mind three things. Firstly, we have left out of consideration three-component blends and blends of questionable pronunciation (e.g. trisyllabic $J N A$ and bisyllabic $S K$ in rujna and maskenbal do not have three or two syllables, respectively), which ultimately left us with 193 words, the components of which we have divided into syllables. Secondly, in terms of methodology, Croatian as an inflective language is more demanding in the description of blends than the English language simply because the establishment of source forms is somewhat dependent on the researcher's arbitrary decision. In verbs, the number of syllables can vary between infinitive and present (cf. inf. izgorjeti 'to burn' [iz.go.rje.ti] and ps. izgori [iz. go.ri]), while nouns and adjectives in the nominative case and masculine gender often have one less syllable than, for instance, the genitive case and feminine gender. Thirdly, it is questionable which syllables are to be counted in cases such as Drnisch-Partenkirchen, grobovlasnik or hirotvorac - only the ones that are blended, or the syllables of the entire source compound. But since such doubts have to do with the first and second component (therefore, the same criteria apply to both), we believe that ultimately the differences in counting will cancel each other out. The results in number of syllables were as follows: on average,

\footnotetext{
${ }^{46} \mathrm{Cf}$. Marković, Klindić, and Borković, Hrvatski rječnik stopljenica.
}

${ }^{47}$ Cf. Kelly, "To »brunch« or to »brench«," and Bauer, "Blends". 
the 200 analysed first components have 2.62 syllables, while the 200 analysed second components have 3.09 syllables, which gives us a ratio of $1.00: 1.18$. Truth be told, this is less than expected. For the sake of comparison, here are Kelly's data obtained for the English language ${ }^{48}$ : on average, the first component has 2.2 syllables, the second component has 2.7 syllables, and the ratio is $1.00: 1.23$.

We said earlier (see § 2) that blending does not necessarily entail clipping of phonetic material, but can also entail overlapping of the same phonetic material of two words. We assumed - based on insight into the material of the Croatian Dictionary of Blends ${ }^{49}$ - that in Croatian there are many more blends with overlapping (i.e., strictly speaking, overlaps) than there are blends with clipping. We have tested and corroborated this assumption on 210 blends from Feral. If we were strict in our analysis and considered as overlapping even cases with one common consonant (e.g. Cadillac $\times$ CCCC, Hrvat 'Croat' $\times$ Srbin 'Serb') or cases of congruent consonant-vocal sequences (e.g. Lazanski $\times$ Ceauşescu, studeni 'November' $\times$ novembar 'November', Tito $\times$ Tutankhamon), there would be only a handful of examples which we would be able to describe as non-overlapped:

alahur (Alah 'Allah' × božur 'peony') (FT, 16 Apr 1989)

Dubala (/Simo/ Dubajić × /Eugène/ Delacroix) (FT, 23 Nov 1990) Hadezejot (ha de ze 'HDZ /Croatian Democratic Union/' $\times$ es ef er jot 'SFRJ /Socialist Federative Republic of Yugoslavia/') (FT, 15 May 1991)

infladendron (inflacija 'inflation' $\times$ rododendron 'rhododendron') (FT, 16 Apr 1989)

Slobault (/Slobodan Milošević/ Slobo $\times$ Foucault $\times$ Renault) $(F T$, 3 Dec 1989)

Štrumpfsar (štrumpf 'Smurf' × Gusar 'Pirate') (FT, 24 Feb 1985)

If we now discard examples with only one component clipped and the other fully preserved ${ }^{50}$, we are left with infladendron and Slobault. If we discard Slobault due to vocal congruity (cf. [slobo] $\times$ [fuko] $\times$ [reno]), we are left only with infladendron as the single example (out of a total of 210) of blend with a clipped ending of the first component and a clipped beginning of the second.

\footnotetext{
${ }^{48}$ Kelly, "To »brunch« or to »brench«," 582.

${ }^{49}$ Marković, Klindić, and Borković, Hrvatski rječnik stopljenica.

${ }^{50}$ Cf. exceptions from rule (4) in Bauer, "Blends", 15.
} 
We merely state the fact, without considering it a shortcoming, that almost all blends in our corpus are, therefore, based on overlapping. But this fact makes it markedly more difficult to research them in terms of syllable boundaries, let alone to research sections of syllables that participate in the making of monosyllabic blends, the instances of which, in our corpus, are only (El) Splitt and Zaag, and they are recognizable only in writing and not in speech ${ }^{51}$. The Croatian language has blends with no overlapping; we can provide three examples taken from slang ${ }^{52}$ :

doviderči (doviđenja 'see you'× It. arrivederci 'see you, goodbye') (slang, Zagreb, 1990-e)

figuar (fićek 'Zastava 750 automobile’× Jaguar) (Bednjanec, Nježni sport, 1980) tretvrti (treći 'third' × četvrti 'fourth') (slang, Zagreb, 2012)

but we find no such blends in the corpus from Feral examined here.

5.

In conclusion, the weekly Feral Tribune from the 1990s and 2000s is the most abundant source in the Croatian Dictionary of Blends ${ }^{53}$. In this paper we have found that in its predecessor Feral, published from 1983 to 1993 , blends occurred in greater number in 1989, i.e. at the very end of the 1980s. Until then, there were less blends in Feral than in the "serious" Nedjeljna Dalmacija weekly. This means that - as far as we can tell at this stage of research - comics author Ivica Bednjanec remains, as far as we know, the most prolific Croatian blend-maker in the 1980s.

In respect of the meaning- and form-characteristics of blends in Feral, we have ascertained the following. Firstly, $80 \%$ of a total of 210 blends are nouns, which matches the data in the Croatian Dictionary of Blends ${ }^{54}$. Secondly, in $46 \%$ of the blends one of the components is a name. In $61 \%$ of the cases the name is the blend's first component.

\footnotetext{
${ }^{51}$ Cf. rule (7) in Bauer, "Blends", 16, pertaining to the onset and rhyme of monosyllabic blends.

${ }^{52}$ Cf. Marković, Klindić, and Borković, Hrvatski rječnik stopljenica, s. v.

${ }_{53}$ Marković, Klindić, and Borković, Hrvatski rječnik stopljenica.

${ }^{54}$ Marković, Klindić, and Borković, Hrvatski rječnik stopljenica.
} 
Thirdly, in a relatively large number of blends one of the components is an acronym (13\%). In $69 \%$ of the cases the acronym is the blend's first component. We conclude, therefore, that the informationally more prominent component (name or acronym) tends to have the initial position. Since it is well-known that beginnings of words are informationally more important than endings of words (at least in languages with inflection at the right end of words, which applies to the vast majority of world languages), this should come as no surprise. Fourthly, the blend's first component will generally be shorter and have less syllables than the second. The number of syllables ratio in the examined corpus is approximately $1.00: 1.18$. Fifthly, blends with simultaneous clipping of the first component's ending and the second component's beginning are extremely rare. Blends in the examined corpus are based on overlapping of the same phonetic material of the first and second component.

We have herewith exhaustively presented Croatian blending in the 1980s and provided guidelines for possible further research which would be conducive to better cross-linguistic comparisons.

\section{Appendix. Blends in Feral and Feral Tribune 1983-19935}

alahur $n$. (Alah 'Allah' × božur 'peony') (FT, 16 Apr 1989)

anarhideja $n$. (anarhija 'anarchy $\times$ orhideja 'orchid') (FT, 16 Apr 1989)

antebeljokratski adj. (Ante Beljo $\times$ antibirokratski 'anti-bureaucratic') (FT, 14 Aug 1991)

Antez $n$. (Ante /Marković/ × /Javier/ Pérez /de Cuéllar/) (FT, 18 Jan 1991)

antisuncijalistički adj. (sunce 'sun' $\times$ antisocijalistički 'anti-socialist') (FT, 4 Jan 1991)

Asserbiated Press $n$. (Associated Press $\times$ Serbia) (FT, 12 Jun 1991)

Autonomijanović $n$. (autonomija 'autonomy' $\times$ /Dragutin/ Tadijanović) (FT, 9 Sep 1990)

beljača $n$. (beljiti se 'to stick your tongue out' × veljača 'February') (FT, 3 Feb 1993, 10 Feb 1993)

Beoghdad $n$. (Beograd 'Belgrade' $\times$ Baghdad) (FT, 18 Jan 1991)

Beogić $n$. (Beograd 'Belgrade' $\times$ Bogić /Bogićević/) (FT, 18 Jan 1991)

\footnotetext{
${ }^{55}$ We record blends in accordance with the principles laid down in Marković, Klindić, and Borković, Hrvatski rječnik stopljenica, but full entries with contextualized token and clarifications are omitted for the sake of conciseness. Abbreviations: $n .=$ noun, adj. $=$ adjective, $v .=$ verb,$a d v .=$ adverb, $p s .=$ present,$i m p .=$ imperative, $s g .=$ singular, $p l .=$ plural, comp .

= comparative. The sign ? indicates a questionable component.
} 
Beogićević n. (Beograd 'Belgrade' × /Bogić/ Bogićević) (FT, 18 Jan 1991) beskuće $n$. (beskućnik 'homeless person' $\times$ bespuće 'wasteland') (FT, 5 Feb 1992)

besnik $n$. (Serb. bes 'rage' $\times$ Serb. pesnik 'poet') (FT, 12 Apr 1991)

besposlovica $n$. (besposlen 'idle' × poslovica 'proverb') (FT, 12 Mar 1989)

Bespućin $n$. (Bespuća /povijesne zbiljnostil 'Wastelands /of Historical Reality/' $\times$ /Grigori Yefimovich/ Rasputin) (FT, 15 May 1991)

Birlin $n$. (Biograd $\times$ Berlin) (FT, 24 Dec 1991)

Bivšević $n$. (bivši 'ex-' × /Hidajet Hido/ Biščević) (FT, 1 Apr 1992)

bludež $n$. (blud 'debauchery' × /Viva/ Ludež '/Viktor Ivančić/ Lucić Dežulović') (FT, 16 Sep 1992)

bljujan $n$. (bljuvati 'to vomit' $\times$ rujan 'September') (FT, 4 Sep 1991)

boljkovševizam $n$. (/Josip/ Boljkovac $\times$ boljševizam 'Bolshevism') (FT, 28 Dec 1990)

Bombetko $n$. (bomba 'bomb' × /Ivan/ Bobetko) (FT, 7 Aug 1991)

bontron $n$. (bonton 'good manners' $\times$ tron 'throne') (FT, 15 Jul 1992)

Brozart $n$. (/Josip/ Broz $\times /$ Wolfgang Amadeus/ Mozart) (FT, 8 Jan 1992)

brukovni adj. (bruka 'disgrace' × strukovni 'vocational') (FT, 16 Dec 1992)

CadillaCCCC $n$. (Cadillac $\times$ CCCC 'four Cyrillic Ss of the Serbian national coat of arms') (FT, 25 Mar 1990)

Cninton $n$. (/Bill/ Clinton $\times$ Knin) $(\mathrm{FT}, 17$ Feb 1993)

crosinac $n$. (Croatia $\times$ prosinac 'December) (FT, 2 Dec 1992)

Cuellarković $n$. (/Javier Pérez de/ Cuéllar × /Ante/ Marković) (FT, 18 Jan 1991)

čelani $a d v$. (/Joško/ Čelan $\times$ lani 'last year') (FT, 25 Nov 1992)

čobanovina $n$. (čoban 'yokel' $\times$ banovina 'bannat') (FT, 29 Mar 1991)

čobanovinski adj. (čobanski adj. 'yokel' × banovinski adj. 'bannat') (FT, 29 Mar 1991)

deflormaster $n$. (deflorirati 'to deflower' $\times$ flomaster 'felt-tip pen') (FT, 8 Sep 1985)

dezerterac $n$. (dezerter 'deserter' $\times$ deseterac 'decasyllable') (FT, 24 Jul 1991)

dimljina $n$. (dim 'smoke' $\times$ divljina 'wilderness') (FT, 11 Mar 1992)

Dražulović $n$. (Draža /Mihajlović/ × /Boris/ Dežulović) (FT, 14 Oct 1992)

Drnisch-Partenkirchen $n$. (Drniš $\times$ Garmisch-Partenkirchen) (FT, 24 Dec 1991)

držnedajnost $n$. (državnost 'statehood' $\times$ drž-ne daj 'touch and go') (FT, 29 Apr 1990)

Drniša $n$. (Drniš × /Dražen/ Budiša) (FT, 29 Jul 1992)

dvornografija $n$. (dvor 'court' $\times$ pornografija 'pornography') (FT, 18 Dec 1991)

Dubala $n$. (/Simo/ Dubajić × /Eugène/ Delacroix) (FT, 23 Nov 1990) 
Dupajić $n$. (dupe 'arse' × /Simo/ Dubajić) $($ FT, 1 Oct 1989)

EI Splitt $n$. (El Shatt $\times$ Split) (FT, 13 May 1992, 20 May 1992)

En dessant $n$. (En passant $\times$ desant 'landing operation') (FT, 29 May 1991)

Eurbija $n$. (Europa 'Europe' $\times$ Srbija 'Serbia') (FT, 26 Apr 1991)

Ferault $n$. (Feral $\times$ Foucault) (FT, 3 Dec 1989)

filharmonika $n$. (filharmonija 'philharmonic' $\times$ harmonika 'accordion') (FT, 23 Oct 1991)

general-vlajor $n$. (general-major 'Major General' $\times$ Vlaj 'man from hinterland of Split') (FT, 4 Jan 1991)

Glupiter $n$. (glup 'dumb' $\times$ Jupiter) (FT, 4 Jan 1991)

glupiterski adj. (glup 'dumb' × jupiterski adj. 'Jupiter’) (FT, 4 Jan 1991)

grobovlasništvo $n$. (grob 'grave' × robovlasništvo 'slave-ownership') (FT, 4 Mar 1992)

grozaik $n$. (groza 'dread' $\times$ prozaik 'prosaist') $(\mathrm{FT}, 12$ Apr 1991)

gusical $n$. (guzica 'arse' $\times$ musical) $(\mathrm{FT}, 10 \mathrm{Jul} 1991)$

guzikl $n$. (guzica 'arse' × mjuzikl 'musical') (FT, 10 Jul 1991)

Hadezejot $n$. (ha de ze 'HDZ /Croatian Democratic Union/' $\times$ es ef er jot 'SFRJ, Socialist Federative Republic of Yugoslavia') (FT, 15 May 1991)

hapsolutan adj. (hapsiti 'to arrest' $\times$ apsolutan adj. 'absolute') (FT, 27 May 1992)

hina $n$. (HINA 'Croatian News Agency' $\times$ mina 'mine, explosive') (FT, 15 Apr 1992)

hiniran adj. (HINA ‘Croatian News Agency' × miniran 'mined') (FT, 15 Apr 1992)

hinski adj. (HINA 'Croatian News Agency’ × minski adj. 'mine') (FT, 15 Apr 1992)

hirotvorac $n$. (hir 'whim' $\times$ mirotvorac 'peace-maker') (FT, 8 Apr 1992)

hirotvoran adj. (hir 'whim' × mirotvoran adj. 'peace-making') (FT, 8 Apr 1992)

hirotvorstvo $n$. (hir 'whim' × mirotvorstvo n. 'peace-making') (FT, 8 Apr 1992)

histeričar $n$. (historičar 'historian' × histerija 'hysteria') (FT, 7 Jan 1990, 14 Jan 1990)

Histerija $n$. (histerija 'hysteria' × / Jovan Popović/ Sterija) (FT, 3 Jun 1992)

horrorskop $n$. (horror $\times$ horoskop 'horoscope') (FT, 19 Mar 1989)

hosovina $n$. (HOS 'Croatian Defense Forces' $\times$ osovina 'axis') (FT, 5 Aug 1992)

Hrbin $n$. a. (Hrvat, hrvatski 'Croat, Croatian' $\times$ Srbin 'Serb') (FT, 13 May 1990) b. (Hrvat $\times$ Srbin) $(\mathrm{FT}, 24$ Jul 1991) 
hrvanj $n$. (?Hrvat 'Croat' $\times$ ?hrvati se 'to wrestle $\times$ srpanj 'July') (FT, 8 Jul 1990, 15 Jul 1990)

Hrvatinac $n$. (Hrvat 'Croat' × Dalmatinac 'Dalmatian') (FT, 29 Jul 1990)

hrvoligaš $n$. (Hrvatska, hrvatski 'Croatia, Croatian' $\times$ prvoligaš 'premier league member') (FT, 1 Apr 1992)

Huškanac $n$. (huškati 'to stir up' × Tuškanac) (FT, 5 Apr 1991)

infladendron $n$. (inflacija 'inflation' $\times$ rododendron 'rhododendron') (FT, 16 Apr 1989)

izgori $n$. pl. (izgorjeti 'to burn up' ps. 3. pl. izgori 'burn-ups' $\times$ izbori 'elections') (FT, 8 Jul 1992)

Izgubiša $n$. (izgubiti 'to lose' × /Dražen/ Budiša) (FT, 27 Jan 1993)

izlažov $n$. (izlagač 'exhibitor' × lažov 'liar') (FT, 1 Oct 1989)

jarnjuar $n$. (/Ivan/ Jarnjak $\times$ Serb. januar 'January') (FT, 8 Jan 1993, 13 Jan 1993)

jatni adj. (JAT 'Yugoslavian Airways' × ratni adj. 'war') (FT, 8 Apr 1992)

Jazuovka $n$. (JAZU 'Yugoslavian Academy of Sciences and Arts' $\times$ Jazovka) (FT, 8 Mar 1991)

Kadam n. (/Veljko/ Kadijević $\times$ Saddam /Hussein/) (FT, 4 Jan 1991)

kalibri $n$. (kalibar 'calibre' $\times$ kolibri 'humming-bird') (FT, 28 Dec 1990)

kaptolicizam $n$. (Kaptol $\times$ katolicizam 'catholicism') (FT, 12 Feb 1992)

kaptoličanstvo $n$. (Kaptol $\times$ katoličanstvo 'catholicism') (FT, 12 Feb 1992)

Klaunprofor $n$. (klaun 'clown' $\times$ UNPROFOR 'United Nations Protection Force') (FT, 20 May 1992)

klipanj $n$. (klip 'piston' × klipan 'lummox' × lipanj 'June') (FT, 31 Dec 1991)

Knindijanac $n$. (Knin $\times$ Indijanac n. 'Native American') (FT, 19 Feb 1992)

knindijanski adj. (Knin $\times$ indijanski adj. 'Native American') (FT, 19 Feb 1992)

kolobroz $n$. (kolovoz 'August' × ?/Josip/ Broz) (FT, 14 Aug 1991, 21 Aug 1991)

komemomentar $n$. (komemoracija 'commemoration' $\times$ komentar 'comment') (FT, 13 Jan 1993)

kompederacija $n$. (konfederacija 'confederation' × peder n. 'gay') (FT, 15 Jul 1990)

kompederativan adj. (konfederativan 'confederative' $\times$ peder n. 'gay') (FT, 15 Jul 1990)

kontrarevolucepcija $n$. (kontrarevolucija 'counter-revolution' $\times$ kontracepcija 'contraception') (FT, 20 Nov 1991)

kosarka $n$. (KOS 'Counter-Intelligence Service' × košarka 'basketball') (FT, 29 Jan 1992)

Kosovac $n$. (KOS 'Counter-Intelligence Service' × /Obrad/ Kosovac) (FT, 1 Feb 1991) 
kospirativan $n$. (KOS 'Counter-Intelligence Service' $\times$ konspirativan 'conspiratorial') (FT, 1 Feb 1991)

košmarka $n$. (košmar 'nightmare' × košarka 'basketball') (FT, 8 Apr 1992)

krađevinarstvo $n$. (krađa 'theft' $\times$ građevinarstvo 'civil engineering') (FT, 11 Mar 1992)

kreveljača $n$. (kreveljiti se 'to make faces' × veljača 'February') (FT, 31 Dec 1991)

Kroacia $n$. (Kroacija $\times$ CIA 'Central Intelligence Agency') (FT, 28 Dec 1990)

krpanj $n$. (?/Drago/ Krpina $\times$ krpa 'rag' $\times$ srpanj 'July') (FT, 1 Jul 1992, 8 Jul 1992)

krunolist $n$. (kruna 'crown' $\times$ runolist 'edelweiss') (FT, 16 Apr 1989)

Kumrowait $n$. (Kumrovec $\times$ Kuwait) (FT, 8 Apr 1992)

kunilingvist $n$. (kunilinktus 'cunnilingus' $\times$ lingvist 'linguist') (FT, $31 \mathrm{Jul}$ 1991)

kunilingvistički adj. (kunilinktus 'cunnilingus' $\times$ lingvistički 'linguistic') (FT, 9 Dec 1992)

kupress $n$. (Kupres $\times$ press) (FT, 22 Apr 1992)

Lazanescu $n$. (/Miroslav/ Lazanski × /Nicolae/ Ceauşescu) (FT, 4 Feb 1990)

LE PEN $n$. (/Jean-Marie/ Le Pen $\times$ PEN 'Poets, Essayists and Novelists') (FT, 16 Dec 1992)

Lubanja $n$. a. (lubanja 'skull' $\times$ banja 'spa') (FT, 2 Sep 1992) b. (lubanja 'skull' $\times$ banj adj. 'Ban') (FT, 2 Sep 1992)

Maladona $n$. (/Boris/ Malada $\times /$ Diego Armando/ Maradona) $(F T, 15$ Oct 1989)

maskenbal $n$. (maskenbal 'masked ball' $\times$ SK 'League of Communists') (FT, 4 Mar 1990)

mesvrstani adj. $n$. (/Stjepan/ Mesić × nesvrstani 'non-alligned') (FT, 15 May 1991)

Miroslae $n$. (Miroslav/Lazanski / × Nicolae/Ceauşescu/) (FT, 4 Feb 1990)

momodrama $n$. (/Momir Bulatović / Momo $\times$ monodrama) (FT, 23 Oct 1991)

moržemo v. ps. 1. pl. (morž 'walrus' $\times$ moći 'to be able to' ps. 1. pl. možemo 'we are able to') (FT, 25 Mar 1992)

motokultiviran adj. (motokultivator 'motor cultivator' $\times$ kultiviran 'cultivated') (FT, 5 Feb 1992)

Muppet $n$. (MUP 'Ministry of Interior' $\times$ Muppet/show/) (FT, 18 Jan 1991)

napalmet $a d v$. (napalm $\times$ napamet 'by heart') (FT, 17 Jun 1992)

nestaša $n$. (nestašan 'mischievous' $\times$ ?ustaša n. 'Ustasha') (FT, 1 Oct 1989)

nestaški adj. (nestašan 'mischievous' $\times$ ?ustaški adj. 'Ustasha') (FT, 1 Oct 1989) 
Orjun $v$. Seral Orjun

Ozdvonimir $n$. (odzvoniti in odzvonilo mu je 'his time is up' $\times$ Zvonimir / Šeparović/) (FT, 26 Aug 1992)

oznati $v$. (OZNA 'Department for the People's Protection' $\times$ znati 'to know') (FT, 29 Jan 1992)

oznovitelj $n$. (OZNA 'Department for the People's Protection' $\times$ obnovitelj 'renewer') (FT, 22 Apr 1992)

Pearl Drwar $n$. (Pearl Harbour $\times$ Drvar $\times$ war $)($ FT, 12 Jun 1991)

pobjesničar $n$. (povjesničar 'historian' $\times$ bijes 'rage') (FT, 7 Jan 1990, 14 Jan 1990)

pogroman adj. (pogrom $\times$ ogroman 'huge') (FT, 1 Oct 1989)

pokrštenica $n$. (pokršten 'forcefully baptized' $\times$ Serb. ukrštenica 'crossword puzzle') (FT, 15 Feb 1991)

Popušje $n$. (popušiti 'to lose' $\times$ Posušje) (FT, 28 Oct 1992)

poraznorazni adj. (porazni 'devastating' $\times$ raznorazni 'miscellaneous') (FT, 27 May 1990)

Pošalić $n$. (pošalica ‘joke’ × /Ivić/ Pašalić) (FT, 9 Dec 1992)

prahašk $n$. (prašak 'powder' $\times$ HAŠK 'Croatian Academic Sport Club') (FT, 25 Mar 1992)

prcalo $n$. (prcati 'to fuck' $\times$ zrcalo 'mirror') (FT, 7 Aug 1991)

preferendum $n$. (?preferirati 'to prefer' $\times$ referendum) (FT, 15 May 1991)

preglupiranje $n$. (pregrupiranje 'regrouping' $\times$ glupiranje 'acting silly') (FT, 26 Feb 1992)

pričuvativ $n$. (pričuva 'reserve' $\times$ prezervativ 'condom') (FT, 20 Nov 1991)

priglupljivač $n$. (priglup 'dim' comp. prigluplji 'dimmer' $\times$ prigušivač 'silencer') (FT, 2 Sep 1992)

primatizacija $n$. (primat 'primate' $\times$ privatizacija 'privatisation') (FT, travanj 1993)

Prkačičin-Šain $n$. (/Ante/ Prkačin $\times$ /Ante/ Čičin-Šain) (FT, 2 Dec 1992)

prkosinac $n$. (prkos 'defiance' $\times$ prosinac 'December') (FT, 23 Dec 1992, 28 Dec 1992)

prkosno $a d v$. (prkosno 'defiant' $\times$ KOS 'Counter-Intelligence Service') (FT, 1 Feb 1991)

prosvinjac $n$. (prosinac 'December' $\times$ svinjac 'pigsty') (FT, 11 Dec 1991, 18 Dec 1991)

puškarac $n$. (puška 'rifle' × muškarac 'man') (FT, 8 Apr 1992)

ratletika $n$. (rat 'war' $\times$ ?ratluk 'Turkish delight' $\times$ atletika 'athletics') $(\mathrm{FT}, 8$ Apr 1992)

rodoljubičica $n$. (rodoljub 'patriot' × ljubičica 'violet') (FT, 16 Apr 1989)

robotomija $n$. (robot $\times$ lobotomija 'lobotomy') (FT, 2 Dec 1992) 
rujna $n$. gen. (rujan 'September' $\times$ JNA 'Yugoslavian People's Army') (FT, 30 Sep 1992)

sabortus $n$. (Sabor 'Croatian Parliament' × abortus 'abortion') (FT, 5 Feb 1992)

samostan adj. (samostan 'monastery' $\times$ samostalan 'autonomous') (FT, 12 Feb 1992)

samostanost $n$. (samostan 'monastery' $\times$ samostalnost 'autonomy') (FT, 12 Feb 1992)

satirikonj $n$. (satirikon 'satyricon' $\times$ konj 'horse') (FT, 4 Mar 1984)

sekskluzivno $a d v$. (seks 'sex' $\times$ ekskluzivno 'exclusive') (FT, 16 Sep 1992)

Seral Orjun $n$. (srati 'to crap' ps. 3. sg. sere 'he craps' $\times$ Feral /Tribune/, Orjuna 'Organisation of Yugoslav Nationalists' $\times /$ Feral/ Tribune) $($ FT, 14 Oct 1992)

sivotinjski adj. (SIV 'Federal Executive Council' $\times$ životinjski adj. 'animal') (FT, 3 Jul 1988)

sjebanj $n$. (sjeban 'fucked up' × siječanj 'January') (FT, 41 1991, 11 Jan 991)

sjebnica $n$. (sjebati 'to fuck up' × sjednica 'meeting, session') (FT, 17 Sep 1989)

skalpinist $n$. (skalp 'scalp' $\times$ alpinist 'rock climber') (FT, 18 Nov 1992)

skalpinizam $n$. (skalp 'scalp' $\times$ alpinizam 'rock climbing') (FT, 18 Nov 1992)

Slobault $n$. (/Slobodan Milošević/ Slobo $\times$ Foucault $\times$ Renault $)(F T, 3$ Dec 1989)

Slobodam $n$. (Slobodan /Milošević/ × Saddam /Hussein/) (FT, 18 Jan 1991)

spermodinamika $n$. (sperma 'sperm' $\times$ termodinamika 'thermodynamics') (FT, 22 Jan 1992)

spisac $n$. (spisak 'list' × pisac 'writer, author') (FT, 16 Dec 1992)

spisan adj. (spisak 'list' $\times$ pisan 'written') (FT, 16 Dec 1992)

spizdanj $n$. (spizditi 'to squander' $\times$ svibanj 'May') $(\mathrm{FT}, 31$ Dec 1991)

spolarni adj. (spolni 'sexual' $\times$ polarni 'polar') (FT, 13 Nov 1991)

sprdačan adj. (sprdnja $n$., sprdati se v. 'ridicule' $\times$ srdačan 'friendly') (FT, 25 Nov 1992)

sprdanj $n$. (sprdati se v. 'ridicule' $\times$ srpanj 'July') (FT, 17 Jul 1991)

Srambo $n$. (srati 'to crap' $\times$ ?Srbija 'Serbia' $\times$ Rambo) $($ FT, 25 Jan 1991)

SRAO $n$. (srati 'to crap' $\times$ SAO 'Serbian Autonomous District') (FT, 11 Jan 1991, 15 May 1991, 12 Jun 1991)

srbanj $n$. (Srbin 'Serb' × srpanj 'July') (FT, 10 Jul 1991, 24 Jul 1991)

Srvat $n$. (Srbin 'Serb' $\times$ Hrvat 'Croat') (FT, 24 Jul 1991)

stravanj $n$. (strava 'horror' $\times$ travanj 'April') (FT, 31 Dec 1991, travanj 1993)

stravni adj. (strava 'horror' $\times$ pravni 'legal') (FT, 5 Feb 1992)

strujan $n$. (struja 'current, electricity' $\times$ rujan 'September') (FT, 2 Sep 1992, 16 Sep 1992) 
studembar $n$. (studeni 'November' $\times$ novembar 'November') (FT, 23 Nov 1990)

suncijalistički adj. (sunce 'sun' × socijalistički adj. 'socialist') (FT, 4 Jan 1991) suncokreten $n$. (suncokret 'sunflower' $\times$ kreten 'cretin') (FT, 4 Jan 1991)

suživotinjski adj. (suživot 'coexistence' × životinjski adj. 'animal') (FT, 18 Mar 1992, 25 Mar 1992)

sveudrilišni adj. (sveučilišni adj. 'university' × udriti 'to hit' imp. 2. sg. udri 'hit') (FT, 22 Mar 1991)

sveudrilištarac $n$. (sveučilištarac 'university student' $\times$ udriti 'to hit' imp. 2. sg. udri 'hit') (FT, 22 Mar 1991)

svršishodan adj. (svršiti 'to have an orgasm' $\times$ svrsishodan adj. 'purposeful') (FT, 20 Nov 1991)

svršishodno $a d v$. (svršiti 'to have an orgasm' $\times$ svrsishodno adv. 'purposeful') (FT, 20 Nov 1991)

stolicizam $n$. (stolica 'chair' $\times$ stoicizam 'stoicism') $(\mathrm{FT}, 8$ Jan 1984)

šekstati $v$. šeksću ps. 3. pl. (/Vladimir/ Šeks $\times$ štektati 'to yelp' ps. 3. pl. štekću 'they yelp') (FT, 21 Dec 1990)

šeksualni adj. (/Vladimir/ Šeks $\times$ seksualni adj. 'sexual') (FT, 7 Aug 1991, 27 May 1992)

šempjun $n$. (̌̌empijan adj. 'crack-brained' × Serb. jun 'june') (FT, 5 Jun 1991, 12 Jun 1991)

Šimeini $n$. (Šime /Đodan/ × /Ruhollah/ Khomeini) (FT, 8 Jul 1990)

špijunir $n$. (̌́pijun 'spy' $\times$ pionir 'Young Pioneer') (FT, 2 Sep 1992)

Špiljkuljan $n$. (/Mika/ Špiljak × /Marija Peakić-/Mikuljan) (FT, 27 May 1992)

Štrumpferal $n$. (štrumpf 'Smurf' $\times$ Feral) $(\mathrm{FT}, 24$ Feb 1985)

Štrumpfsar $n$. (štrumpf 'Smurf' $\times$ Gusar 'Pirate') (FT, 24 Feb 1985)

tenk-van-do $n$. (tenk 'tank, armoured military vehicle' $\times$ Kor. tae-kwon-do) (FT, 14 Aug 1991)

Titankhamon $n$. (/Josip Broz/ Tito $\times$ Tutankhamon) (FT, 3 May 1991)

torblon $n$. (torba 'bag' $\times$ tromblon 'rifle grenade') (FT, 7 Aug 1991)

torblonski adj. (torba 'bag' $\times$ tromblonski adj. 'rifle-grenade') (FT, 7 Aug 1991)

traktorat $n$. (traktor 'tractor' $\times$ doktorat 'doctorate') (FT, 5 Feb 1992)

Tuđmangton $n$. (/Franjo/ Tuđman $\times$ Washington) (FT, 18 Jan 1991)

tupanija $n$. (tupan 'dunce' $\times$ županija 'county') (FT, 1 Feb 1991)

udbisati $v$. (UDBA 'State Security Administration' $\times$ udisati 'to inhale') (FT, 27 May 1990)

udbojka $n$. (UDBA 'State Security Administration' $\times$ odbojka 'volleyball') (FT, 29 Jan 1992) 
udbonosan adj. (UDBA 'State Security Administration' $\times$ sudbonosan 'fateful') (FT, 8 Apr 1990)

udbudljiv adj. (UDBA 'State Security Administration' × uzbudljiv 'exciting') (FT, 3 Dec 1989)

uljudben $n$. (U 'Ustasha' $\times$ UDBA 'State Security Administration' $\times$ uljudben 'civilisational') (FT, 28 Dec 1990)

uzbunbul $n$. (uzbuna 'alert' $\times$ zumbul 'hyacinth') (FT, 16 Apr 1989)

veljkovača $n$. (Veljko /Kadijević/ × veljača 'February') (FT, 1 Feb 1991, 8 Feb 1991)

vjerojauk $n$. (vjeronauk 'religious instruction' $\times$ jauk 'wail') $(\mathrm{FT}, 12 \mathrm{Feb} 1992)$

Vukojevina $n$. (/Vice/ Vukojević $\times$ vukojebina 'God-forsaken hole') (FT, 29 Apr 1992)

Walesar $n$. (/Lech/ Wałęsa × /Dragutin/ Lesar) $(F T, 25$ Nov 1992)

warikina $n$. (war $\times$ varikina 'bleach') (FT, 19 Aug 1992)

yumrak $n$. (Yugoslavia $\times$ sumrak 'twilight') $(\mathrm{FT}, 15$ Jan 1992)

Zaag $n$. (Zagreb $\times$ Haag) (FT, 27 Nov 1991)

zagrebni adj. (Zagreb $\times$ zagrobni adj. 'after-death') (FT, 6 May 1992)

zbilježnica $n$. (zbilja 'reality' $\times$ bilježnica 'notebook') (FT, 19 Feb 1992)

\section{References}

Bagić, Krešimir. "Stopljenica. Riječ, figura, kultura." In Svijet stila, stanja stilistike. Proceedings from the colloquium, 13 Feb 2015. Zagreb: Filozofski fakultet, Stilistika, 2015. Accessed February 3, 2019. http://stilistika.org/bagic. Bednjanec, Ivica. "Nježna magija." Super strip BIS, Zagreb, no. 18 (1975): 37-44. Bednjanec, Ivica. "Nježni robijaš." Kerempuh. Humoristički list, Zagreb, vol. II-III, no. 11-25 (Mar 1975-May 1976).

Bednjanec, Ivica. Nježni sport. Satirička enciklopedija sporta u stripu. Zagreb: Mladost, 1980. Originally published in the SN revija weekly, Zagreb, 1976-1980.

Bednjanec, Ivica. "Nježni sport." SN revija, Zagreb, vol. VI-IX, no. 222-429 (7 Jan 1981-26 Dec 1984).

Bauer, Laurie. "Blends. Core and Periphery." In Cross-disciplinary Perspectives on Lexical Blending, edited by Vincent Renner, François Maniez, and Pierre J. L. Arnaud, 11-22. Berlin: De Gruyter Mouton, 2012.

Bugarski, Ranko. Žargon. Lingvistička studija. Second edition. Beograd: XX vek, Knjižara Krug, 2006.

Bugarski, Ranko. Sarmagedon u Mezopotamaniji. Leksičke skrivalice. Beograd: XX vek, Knjižara Krug, 2013. 
Fauconnier, Gilles, and Mark Turner. The Way We Think. Conceptual Blending and the Mind's Hidden Complexities. New York: Basic Books, 2002.

Freud, Sigmund. Die Traumdeutung. Gesammelte Werke, Bd. II-III (1900-1901). London: Imago Publishing Co., 1900.

Freud, Sigmund. Der Witz und seine Beziehung zum Unbewußten. Gesammelte Werke, Bd. VI (1905). London: Imago Publishing Co., 1905.

Feral Tribune. Sarajevo: Mediacentar, 2010. 4 DVD [no. 416-1185, 1 Jun 1993-20 Jun 2008].

FT = Feral, no. 1-255, Nedjeljna Dalmacija, Split, no. 649-966, 16 Oct 1983-5 Nov 1989; Feral Tribune, no. 256-301, Nedjeljna Dalmacija, Split, no. 967-1013, 12 Nov 1989-30 Sep 1990; Feral Tribune, no. 302-414, Slobodna Dalmacija, Split, XLVIII-[n/a], no. 14361-[n/a], 23 Nov 1990-3 Mar 1993; Feral Tribune, no. 415, Erasmus, Zagreb, no. 1, Apr 1993; Feral Tribune, Split, no. 416-1185, 1 Jun 1993-20 Jun 2008.

Kelly, Michael H. "To »brunch« or to »brench«. Aspects of Blend Structure." Linguistics, vol. 36, no. 3 (1998): 579-590.

Marković, Ivan. “Od Oca do Ćaće. 150 godina hrvatskih stopljenica.” In Hrvatski rječnik stopljenica, edited by Ivan Marković, Ivana Klindić, and Iva Borković. Zagreb: Filozofski fakultet Sveučilišta u Zagrebu, Odsjek za kroatistiku, Katedra za stilistiku, 2016. Accessed February 3, 2019. http://stilistika.org/ od-oca-do-cace.

Marković, Ivan. “Bilješke o jeziku Ante Starčevića.” Filologija 71 (2018): 75-114.

Marković, Ivan, Ivana Klindić, and Iva Borković. Hrvatski rječnik stopljenica. Zagreb: Filozofski fakultet Sveučilišta u Zagrebu, Odsjek za kroatistiku, Katedra za stilistiku, 2016. Accessed February 3, 2019. http://stilistika.org/ hrvatski-rjecnik-stopljenica.

Mataković, Dubravko. Prot. Ratno izdanje. Zagreb: s. n., 1991.

Mataković, Dubravko. I jope Prot pictures. Pterodaktiličarstvo za početnike.

Sisak: Centar za kulturu Vladimir Nazor et al., 1992.

$\mathrm{N} 1=$ http://hr.n1info.com/, Accessed February 3, 2019.

ND = Nedjeljna Dalmacija, Split, 1983-1990.

Novi list $=$ http://www.novilist.hr/Vijesti, Accessed February 3, 2019.

Novosti $=$ https://www.portalnovosti.com/, Accessed February 3, 2019.

Pavelić, Boris. Smijeh slobode. Uvod u Feral Tribune. Second edition. Rijeka: Adamić, 2015.

Renner, Vincent, François Maniez, and Pierre J. L. Arnaud. "Introduction. A Bird's-eye View of Lexical Blending." In Cross-disciplinary Perspectives on Lexical Blending, edited by Vincent Renner, François Maniez, and Pierre J. L. Arnaud, 1-9. Berlin: De Gruyter Mouton, 2012.

Renner, Vincent, François Maniez, and Pierre J. L. Arnaud, eds. Cross-disciplinary Perspectives on Lexical Blending. Berlin: De Gruyter Mouton, 2012.

Štebih Golub, Barbara. "Stopljenice u medijskome i reklamnome diskursu suvremenoga hrvatskog jezika." Poznańskie Studia Slawistyczne 13 (2017): 195-208. 


\section{Hrvatske stopljenice u 1980-ima \\ (Prvih 10 godina Ferala)}

Sažetak: Izvještava se o neistraženu korpusu hrvatskih stopljenica prikupljenih iz prvih deset godišta satiričkoga tjednika Feral ili Feral Tribune te se iznose njihove osnovne formalne odlike.

Utvrđuje se troje. Prvo, stopljenice su u Feralu rijetke sve do 1989, kad postaju izrazito česte, a oblikom i sadržajem iste onima u kasnijem Feral Tribuneu. Drugo, više stopljenica nađeno je u tjedniku Nedjeljna Dalmacija iz 1980-ih negoli u Feralu, koji je u Nedjeljnoj Dalmaciji bio prilog, čime stječemo bolji uvid u opću sliku hrvatskoga stapanja u 1980-ima. Treće, najplodniji tvorac stopljenica u 1980-ima, koliko zasad znamo, ostaje strip-crtač Ivica Bednjanec.

Što se značenjskih i obličnih odlika stopljenica u Feralu tiče, utvrđuje se sljedeće. Prvo, 80\% od ukupno 210 stopljenica jesu imenice. Drugo, 46\% stopljenica kao jednu od svojih sastavnica ima ime. U 61\% slučajeva ime je prva sastavnica stopljenice. Treće, relativno velik broj stopljenica kao jednu od svojih sastavnica ima akronim (13\%). U 69\% slučajeva akronim je prva sastavnica stopljenice. Četvrto, prva sastavnica stopljenice načelno će biti nešto kraća. Odnos broja slogova u obrađenome korpusu jest 1,00 : 1,18. Peto, izrazito su rijetke stopljenice u kojima bi došlo do istodobnog obrezivanja dočetka prve i početka druge sastavnice. Stopljenice obrađenoga korpusa temelje se na pretapanju istoga fonetskoga materijala prve i druge sastavnice.

Ključne riječi: (leksičke) stopljenice, (leksičko) stapanje, pretapanje, hrvatski, Ivica Bednjanec, Feral Tribune 